\title{
電界中に置かれた導電率の異なる内部および外部組織からなる 円柱モデル内の電流分布
}

\author{
正員 千葉敦生（米子高専） \\ 正員 伊坂勝生 (徳島大学)
}

\begin{abstract}
Current Distributions Inside the Cylindrical Model with the Internal and the External Tissues Having Different Conductivities in the Electric Fields

Atsuo Chiba, Member (Yonago National College of Technology),

Katsuo Isaka, Member (The University of Tokushima)
\end{abstract}

\begin{abstract}
The health effect of the weak current induced in the human body as a result of the interaction between human body and power line electric fields has been investigated. A human model(cylindertsemisphere) filled with tissues having different conductivities was used to analyze the internal current densities. In this analysis, only the magnitudes of the induced current densities were analyzed.

In this paper, the finite element method is applied to the analysis of the distributions of the horizontal and vertical currents induced in the cylindrical model. The calculation method is verified by comparing the calculated results with the experimental ones obtained elsewhere. The basic characteristics of the induced current distributions in the cylindrical model with the two tissues having different conductivities have been made clear.
\end{abstract}

キーワード : 有限要素法、円柱モデル、誘導電流密度、電界

\section{1.まえがき}

人体に対する送電線からの静電誘遒によって、送電線近 傍にある金属物体に螌れた際の接触電流、生体表面の電界 および電界による直接誘導電流が引き起こされる。このう ち、電界によって生体内に直接誘導される微小な電流の生 体影響が、人間の健康問題と関連して、送電線電圧の超高 圧化に伴い、ますます重要な研究課題になってきている ${ }^{(1)}$ 。 筆者らの研究は主として、電界により直接生体内に誘導さ れる電流を計算機でシミュレートするものである。

電界により人体に誘尊される電流密度の解析には、球お よび回転だ円体の人体モデルの電界铰密解法 ${ }^{(2)}$ に基づく解 析、 3 次元ブロックモデルの積分方程式による解析 ${ }^{(3),(4)}$ 、 表面電荷法による 3 次元モデルの解析 ${ }^{(5)}$ 、円柱モデルの表 面電荷法による解析 ${ }^{(6)}$ および軸対称モデルの有限要素法解 析(7)がある。これらの解析はいずれの場合もモデル内が均 一な組織で満たされていると仮定されている。しかしなが ら、血液と骨組織の導電率は100倍程度の差があるように、 体内各組織の導電率は異なるので、解析結果を実際に近づ けるためには不均質で構成された人体王デルを検討刘象に する必要がある。そこで、筆者らは最近、有限要素法を用 いて 2 種類の組織で構成された人体モデル（円柱と半球か らなる) 内部に誘導される電流密度の基礎的な検討を行っ
ている(8)。しかしながら、人体モデルの形状が害際の人体 と同程度に複雑になると、体内誘遒電流の水平方向成分は 垂直方向成分より大きくなる部分も生じる(9)。また、不均 質組織により構成されたモデル内部の組織には電流密度の 集中が起こる(8)。このようなモデル内部の誘遒電流の分布 を考察するためには、電流の大きさのみでは不十分で水平 および垂直方向の電流密度の分布および電流の流れる方向 を詳細に検討する必要がある。その第一歩として、上述円 柱と半球からなる人体モデルに代えて、水平および垂值方 向の誘導電流密度分布が実験的に明らかにされているKaune 等の垂直円柱モデルを用い、その内部誘導電流密度分布の 解析を行った。すなはち、筆者らは垂直円柱モデルに有限 要素法を適用し、計算値が実験值と一致するのを確かめた 上で、同モデルが 2 種類の導電率を有する組織で構成され た場合の水平および垂直方向の誘導電流密度分布を解析し た。その結果、本論文において 2 種類の異なった組織で楎 成された円柱モデル内部に誘導される水平および垂直方向 の誘遒電流密度分布の基本的な特性を明らかにした。

\section{2. 有限要素法による解析}

2.1 基本式 その電気的特性が尊電率 $\sigma$ と誘電率 $\varepsilon$ で記述できる媒質において、電界を $\mathrm{E}$, 電流密度をJ、 
空間電荷密度を $q$ とすると、次式が成立する

$$
\begin{aligned}
& \operatorname{div}(\varepsilon E)=q \\
& \operatorname{div} J=\operatorname{div}(\sigma E)=-\frac{\partial q}{\partial t}
\end{aligned}
$$

(1)，(2)式から $\varepsilon$ が時間的に一定であると、静電界問題に対 して、次の基本方程式が成立する。

$$
\operatorname{div}\left\{\sigma \cdot \operatorname{grad} \phi+\frac{\partial}{\partial t}(\varepsilon \cdot \operatorname{grad} \phi)\right\}=0
$$

ここで、 $E=\operatorname{grad} \phi （ \phi:$ 電位）である。

有限要素法はこの問題を、次の沉関数 $\chi$ を最小にする電 位 を求める問題に置き換えて解く方法である。

$$
\chi=\int_{v} \frac{\sigma}{2}(\operatorname{grad} \phi)^{2} d v+\frac{\partial}{\partial t} \int_{v} \frac{\varepsilon}{2}(\operatorname{grad} \phi)^{2} d v
$$

なお、 $v$ は解析対象領域を表す。

角周波数 $\omega$ の交流電生を対象亡する場合、複素電位とし $\tau \phi=\phi \mathrm{e}^{\mathrm{j \omega 1}}$ を用いると(4)式は次のようになる。

$$
\chi=\int_{\nu} \frac{1}{2}(\sigma+j \omega \varepsilon)(\operatorname{grad} \phi)^{2} d \nu
$$

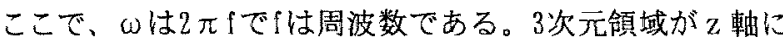
ついて幾何学的対称性を有するとき (5) 式を軸対称問題と して取り扱うと次式が成立する。

$$
\chi=2 \pi \iint\left\{\frac{1}{2}(\sigma+j \omega \varepsilon)\left[\left(\frac{\partial \phi}{\partial r}\right)^{2}+\left(\frac{\partial \phi}{\partial z}\right)^{2}\right] r\right\} d r d z
$$

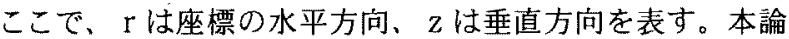
文では、問題とする領域の分割にアイソパラメトリック要 素（軸対称2次四辺形要素）を用い、（6）式を最小にする複 素節点電位を求めた。なお、この要素は複雑な境界の近似 に適しており、かつわずかの要素数で解析対象領域内の電 位が精度よく求められる利点を有している(11)。

\section{2 円柱モテルの形状および計算領域}

Kaune等が行った実験と解析に基づき(6)、円柱モデルを 最も簡単に2種類の異なった組織で構成し、その内部に誘導 される電流密度の解析を行った。円柱モデル（高さ304mm、 半径 $157 \mathrm{~mm})$ は導電率 $\sigma_{a}$ の内部組織と導電率 $\sigma_{b}$ の外部組織 の2種類の組織から構成されている（図 1 参照）。体内各組 織の導電率は周波数 $60 \mathrm{~Hz}$ において、血液の導電率 $0.7 \sim 1.0$ $\mathrm{S} / \mathrm{m}$ ，筋肉、心臓、肝臓、肺の導電率は約 $0.1 \mathrm{~S} / \mathrm{m}$ 、脂肪书よ

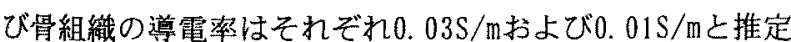
されている(12)(13)。このため、解析に用いた導電率 $\sigma_{a}$ およ び $\sigma_{b}$ の範囲を0.01〜1.0S/mとした。なお、各組織の誘電 率は $10^{6} \varepsilon_{0}, \mathrm{~F} / \mathrm{m}\left(\varepsilon_{0}\right.$ : 真空の誘電率) で一定とした。図 1 に示す円柱モデルをKaune等の実験および解析条件に基づき、 $60 \mathrm{~Hz} 、 1.0 \mathrm{kV} / \mathrm{m}$ の外部平等電界中の地表面上に直立させた。 この外部平等電界の条件を作るため、高さ $10 \mathrm{~m}$ 、半径 $15 \mathrm{~m} の$ 平行円板電極（印加電圧 $10 \mathrm{kV}$ ) 内中心の接地電極面中央に モデルを直立させた。この計算モデルを用いて、モデル内 部に誘導される電流密度の水平および垂直方向成分を求め た。上述計算モデルの計算領域を図2(a)に示す。同図で「は
水平方向、乙は垂直方向の座標を表す。計算領域は有限要素 法のアイソパラメトリック要素で分割されている（要素 数：146、節点数 481）。なお、分割にあたって、円柱モデ ルには42要素をあてた（図2 (b)参照）。

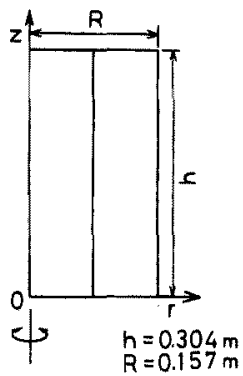

図 12 種類の組織からなる円柱モデルの形状

Fig. 1 Configuration of the cylindrical model.

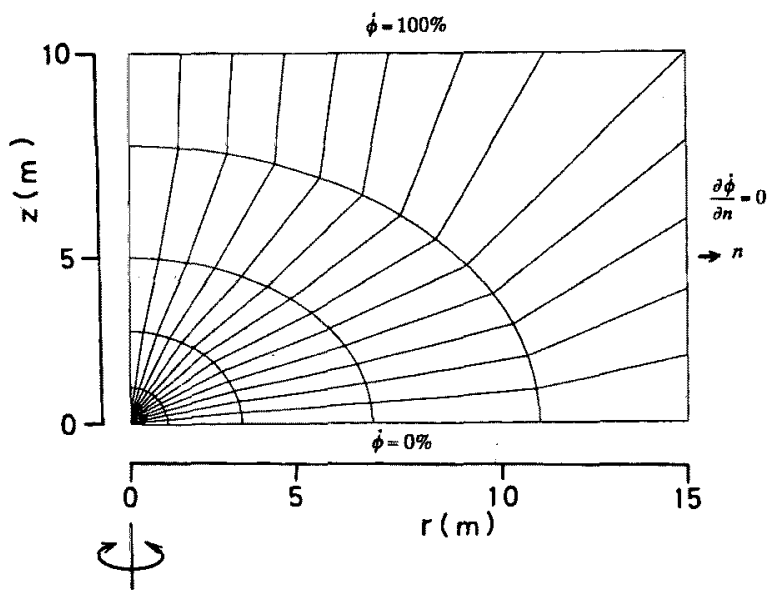

図 2 (a) 全体の分割図

Fig. 2(a) 0verall division pattern.

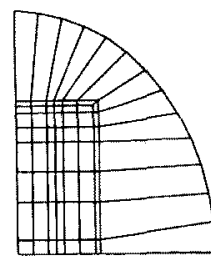

図 2 (b) 円柱モデルとその分割図

Fig. 2(b) Cylindrical model and its division pattern.

\section{3. 解析方法の妥当性の検証}

本解析では、Kaune等が実験に用いた円柱モデル(6)を用 い、ポリ塩化ビニール（PVC、比誘電率3）容器(半径 0.157 m, 高さ0. $304 \mathrm{~m}$ ，厚さ $4.5 \mathrm{~mm}$ ) 内は導電率 $\sigma=0.1 \mathrm{~S} / \mathrm{m}$ 、誘電 率 $\varepsilon_{1}=10^{6} \varepsilon_{0} \quad\left(\varepsilon_{0}:\right.$ 真空の誘電率）を有する溶液で满たさ れていると仮定した。この円柱モデルを $5.65 \mathrm{kV} / \mathrm{m} の$ 外部平 等電界を発生させる平行冈板電極（高さ $10 \mathrm{~m}$ 、半径 $15 \mathrm{~m}$ ）の 接地電極中央に直立させ、2. 2節で述べた解析条件を用いて 有限要素法により解析した。円柱モデル内垂直方向の誘導 
電流密度のKaune等による害験結果と有限要素法によるPVC 容器を考慮した解析結果の比較を図 3 に示す。同図にはモ デル内の高さのファクタ $\mathrm{z} / \mathrm{h}=0.19 ， 0.44 ， 0.66$ 㧍よび 0.9 をパラメタとして半径方向のファクタ $\mathrm{r} / \mathrm{R}$ 垂直方向の誘 導電流密度の関係を示す。図 4 に $\mathrm{r} / \mathrm{R}$ と水平方向の誘導電 流密度の実験結果の比較を示す。図 3 および図 4 から、

Kaune等による实験結果とPVC容器を考慮した有限要素法の 解析結果はよく一致していることがわかる。表 1 に一例と して $\mathrm{r} / \mathrm{R}=0.52$ 地点におけるモデル内に誘導される垂直方向 の電流密度のPVC容器を考慮した場合およびPVC容器なしの 場合の有限要素解析結果と Kaune等による解析および実験 結果の比較を示す。同表からもわかるように、PVC容器を考 慮した誘導電流密度の解析結果によると、モデル底面付近 の電流密度は2. 3\%程度增加する。同梯に、 $\mathrm{r} / \mathrm{R}=0.48$ 地点に おけるモデル内に誘導される水平方向の電流密度の比較を 表 2 に示す。表 1 および表 2 から、PVC容器を考慮した水平 および垂直方向の誘道電流密度の有限要素法の解析結果は Kaune等の実験結果の籁囲内にありよく一致していることが わかる。表1に示されているように、Kaune等の解析結果は モデル底面付近 $z / h=0.19$ 地点の電流密度が実験結果と多少 異なった小さい值で求められている。この計算值はPYC容器 を考慮しないで解析した有限要素法の計算結果とほほ等し くなっている。すなわち、同モデル内部に誘導される水平 および垂直方向の電流密度を有限要素法により解析するこ との妥当性がKaune等の実験結果を用いて検証された。

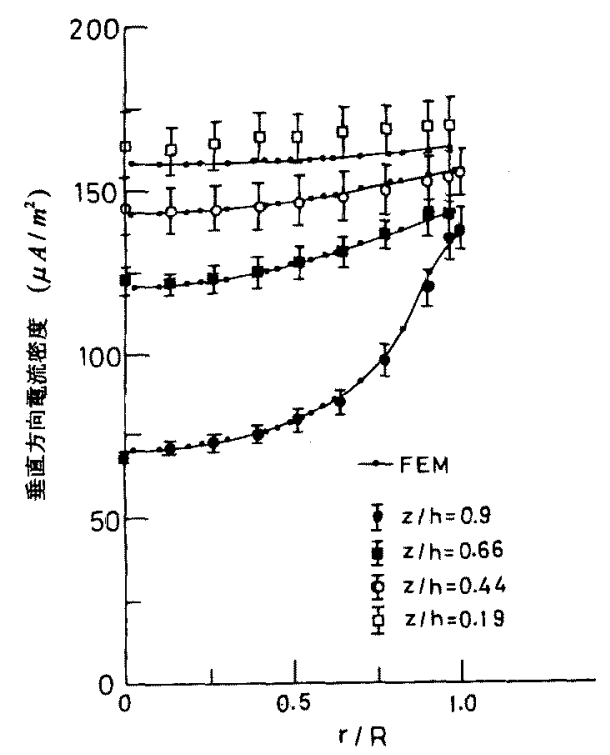

図 3 PVC容器の影響を考慮した円柱モデル内垂直方向 電流密度の有限要素法解析結果々実験結果の比 較（外部電界 $5.65 \mathrm{kV} / \mathrm{m}$ )

Fig. 3 Comparison between the calculated results of the vertical current densities induced inside the cylindrical model in consideration of the PVC shell using FEM and the experimental results. (External field 5.65 $\mathrm{kV} / \mathrm{m})$

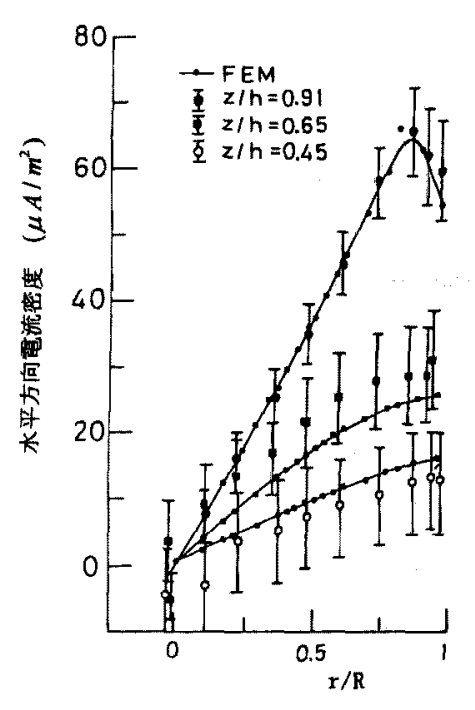

図 $4 \mathrm{PVC}$ 容器の影響を考慮した円柱モデル内水平方向 電流密度の有限要素法解析結果と害験結果の比 較 (外部電界 $5.65 \mathrm{kV} / \mathrm{m}$ )

Fig. 4 Comparison between the calculated results of the horizontal current densities induced inside the cylindrical model in consideration of the PVC shell using FEM and the experimental results. (External field $5.65 \mathrm{kV} / \mathrm{m}$ )

表 1 モデル内垂直方向電流密度の有限要素法解析結 果とKaune 等の解析および実験結果との比較 $(\mathrm{r} / \mathrm{R}=0.52$ 地点 $)$

Table 1 Comparison between the calculated results of the vertical current densities using FEM and the results analyzed or measured by Kaune et al. (at $r / R=0.52$ in the model)

\begin{tabular}{|c|c|c|c|c|}
\hline$z / h$ & $\begin{array}{c}\text { PVC容呾 } \\
\text { なし }\end{array}$ & $\begin{array}{c}\text { PVC容器 } \\
\text { 考慮 }\end{array}$ & $\begin{array}{l}\text { Kaune等の } \\
\text { 解析結果 }\end{array}$ & $\begin{array}{l}\text { Kaune等の } \\
\text { 実験結果果 }\end{array}$ \\
\hline 0.9 & 78.6 & 79.6 & $\frac{74}{75.5}$ & $75.0-83.0$ \\
\hline 0.66 & 124.8 & 127.9 & 123.5 & $123.5--133.0$ \\
\hline 0.44 & 143.5 & 147 & 143.5 & $139.5--153.5$ \\
\hline 0.19 & 154.5 & 158.1 & 155 & $158.0--174.0$ \\
\hline
\end{tabular}

表 2 モデル内水平方向電流密度の有限要素法解析結 果とKaune 等の解析および実験結果との比較 $(\mathrm{r} / \mathrm{R}=0.48$ 地点)

Table 2 Comparison between the calculated results of the horizontal current densities using FEM and the results analyzed or measured by Kaune el al. (at $r / R=0.48$ in the model)

\begin{tabular}{|c|c|c|c|c|}
\hline$z / h$ & $\begin{array}{c}\text { PVC客器 } \\
\text { なL }\end{array}$ & $\begin{array}{c}\text { PVC 容器 } \\
\text { 考虚 }\end{array}$ & $\begin{array}{l}\text { Kaune等の } \\
\text { 解析結果 }\end{array}$ & $\begin{array}{l}\text { Kaune等の } \\
\text { 実験結果 }\end{array}$ \\
\hline 0.91 & 33.9 & 35.8 & 35 & $30.5--39.5$ \\
\hline 0.65 & 16.5 & 17.1 & 16.5 & $14.5--28.5$ \\
\hline 0.45 & 9.3 & 9.5 & 9 & $0=-14.5$ \\
\hline
\end{tabular}




\section{4. 解析結果}

2.2節で述べた2種類の異なった組織で構成された円柱モ テルを用い、生体組織の導電率をパラメータとして、モデ ル内の内外部組織に誘導される電流密度の解析を行った。 解析結果の一例として、図 5 にモデルの高さのファクタz/h を0.9，0.8，0.65，0.45 および0.2として、モデルの半径 方向のファクタ $\mathrm{r} / \mathrm{R}$ と内部誘導電流密度の垂直方向成分 $J_{z}$ の関係を示す。ここで、円柱モデル内部組織の導電率 $\sigma_{a}$ お よび外部組織のそれ $\sigma_{b}$ を、それぞれ 0.1 S/mおよび0.01

S/mとした。同図から、導電率の大きい内部組織内では、 モデルの上部から下部にゆくに従って、垂直方向の電流密 度が大きくなっていることがわかる。また、外部組織内の 組織層境界付近では同様に、モデルの下部にゆくに従って 電流密度の垂㨁方向成分は大きくなるが、この逆に、外部 組織の外側ではモデルの上部にゆくに従って垂直方向の誘 導電流密度が大きくなっている。これは外部組織の外側で 誘遒されたモデル表面電界強度が、モデルの下部から上部 にいくに従って大きくなるためである。内部組織の垂直方 向電流密度を $J_{z a}$ および外部組織のそれを $J_{z b}$ とすると、モ デルの同一高さの内外部組織境界面で、雨組織の電流密度 の垂直方向成分の比 $\left(J_{z a} / J_{z b}\right)$ はほぼそれらの組織の尊電 率の比 $\left(\sigma_{a} / \sigma_{b}\right)$ と等しくなっている。図6にて/hをパラ メータとして、半径方向のファクタ $\mathrm{r} / \mathrm{R}$ と内部誘導電流密 度の水平方向成分 $J_{x}$ の関係を示す。同図から、モデルの 上部にゆくに従って、水平方向に誘導される電流密度は大 きくなり、解析条件下で、内外部組織の境界面でこの值は 最大になっていることがわかる。また、モデルの同一高さ

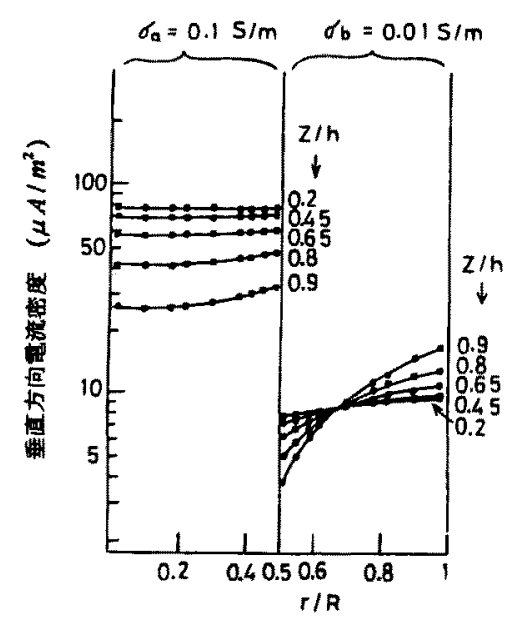

図 5 モデル内半径方向の距離 $\mathrm{r} / \mathrm{R}$ 之垂直方向電流密度 の関係 $\left(\sigma_{a}=0.1 \mathrm{~s} / \mathrm{m}, \sigma_{b}=0.01 \mathrm{~S} / \mathrm{m}\right.$ 場合、外部 電界 $1 \mathrm{kV} / \mathrm{m})$

Fig. 5 Distributions of the vertical current densities inside the model along its $\mathrm{r} / \mathrm{R} . \quad\left(\sigma_{a}=0.1 \mathrm{~S} / \mathrm{m}, \sigma_{b}=\right.$ $0.01 \mathrm{~S} / \mathrm{m}$, external field $1 \mathrm{kV} / \mathrm{m}$ )

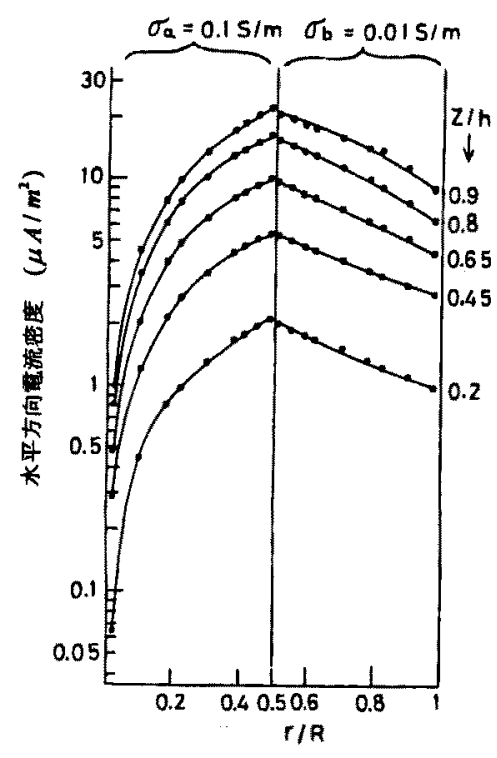

図 6 モデル内半径方向の距離 $\mathrm{r} / \mathrm{R}$ と水平方向電流密度 の関係 $\left(\sigma_{a}=0.1 \mathrm{~S} / \mathrm{m}, \sigma_{b}=0.01 \mathrm{~S} / \mathrm{m}\right.$ の場合、外部 電界 $1 \mathrm{kV} / \mathrm{m})$

Fig. 6 Distributions of the horizontal current densitles inside the model along its $r / R$. $\left(\sigma_{a}=0.1 \mathrm{~s} / \mathrm{m}, \sigma_{b}=0.01 \mathrm{~S} / \mathrm{m}\right.$, external field $\left.1 \mathrm{kV} / \mathrm{m}\right)$

における電流密度の水平方向成分は、両組織の境界面でほ ほ等しくなっていることがわかる。罒7にモデル内に誘導 される電流密度のベクトル図を示す。同図から、モデル上 部において、導電率の小さい外部組織に誘導される電流が 導電率の大きい内部組織に流れ込んでいる様子がよくわか る。また、電流密度の水平方问成分は上部で大きく、中部、 下部にいくに従って著しく減少する。モデルの底面におけ る内外組織の電流密度の比はほぼ両組織の尊電率の比に なっていることも視察できる。内外部組織の導電率がそれ ぞれ $0.1 \mathrm{~S} / \mathrm{m}$ おび $0.01 \mathrm{~S} / \mathrm{m}$ の場合、各組織内の電流密度の 成分 $\left(J_{z a}, J_{z b}, J_{x a}, J_{x b}\right)$ とモデルの高さの関数 $z / h の$ 関 係を図 8 に示す。ここで、内外部組織の垂直方向の電流密 度をそれぞれ $J_{z a}$ および $J_{z b}$ 、水平方向のそれをそれぞ れ $J_{x a}$ および $J_{x b}$ とした。なお、水平および垂直方向の 電流密度は、内外部組織の中央の位置 $(r / R=0.25$ および 0 . 75）において計算された值を用いた。同図から、モデルに 誘導される電流密度の垂直方向成分は、内外部組織で、上 部から下部にゆくに従っで增加していることがわかる。モ デル底面において、雨組織内の垂直方向電流密度の比 $\left(J_{z a} / J_{z h}\right)$ はそれらの導電率の比 $\left(\sigma_{a} / \sigma_{b}\right)$ 亡ほほ等しい。 また、電流密度の水平方向成分は上部から下部にかけて著 しく減少していくが、上部においてはその垂直方向成分より 大きいことがわかる。同モデル内の内外部組織中央の頂面 


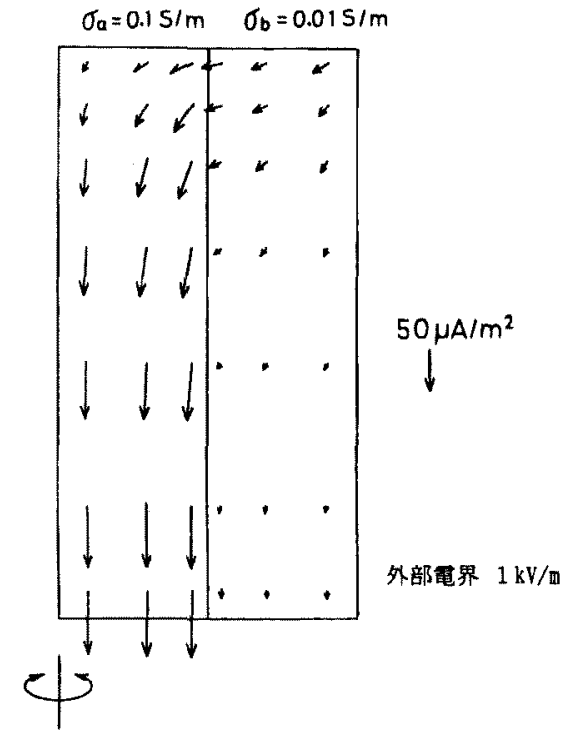

図 7 モデル内電流密度のベタトル図

Fig. 7 Vector diagram of the current density distribution in the model.

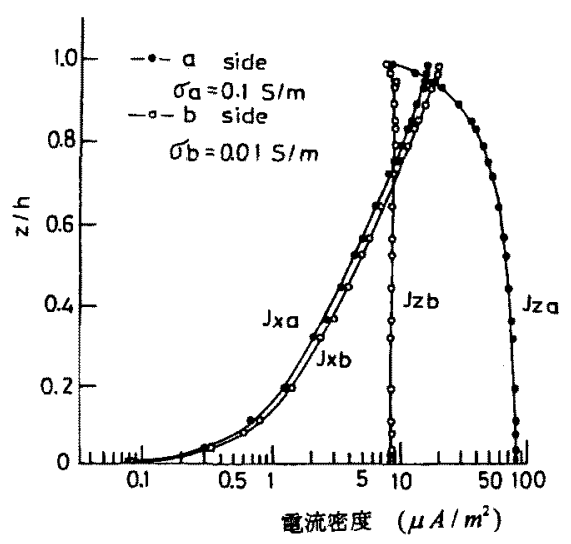

図 8 モデル内垂直および水平方向電流密度と $\mathrm{z} / \mathrm{h}$ の関 係 $\left(J_{x a}\right.$ : 内部組織内水平方向電流密度、 $J_{x b}$ : 外部組織内水平方向電流密度、 $J_{z a}$ : 内部組織内 垂直方向電流密度、 $J_{z b}$ : 外部組織内垂直方向電 流密度、外部電界 $1 \mathrm{kV} / \mathrm{m}$ )

Fig. 8 Distributions of the vertical and horizontal current densities inside the model along its $z /$ h. ( $J_{x n}$ : horizontal current density in the inside tissue, $J_{x b}$ : horizontal current density in the outside tissue, $J_{z a}$ : vertical current density in the inside tissue, $J_{z b}$ : vertical current density in the outside tissue, external field $1 \mathrm{kV} / \mathrm{m}$ )

および底面における導電率の比 $\sigma_{b} / \sigma_{a}\left(\sigma_{a}=0.1 \mathrm{~s} / \mathrm{m}\right.$, $\left.\sigma_{b}=0.01 \sim 1.0 \mathrm{~S} / \mathrm{m}\right)$ と垂直方向電流密度の比 $\left(J_{z \sigma_{b} / \sigma_{a}} / J_{z \sigma_{h} / \sigma_{a}=1}\right)$ の関係を図 9 に示す。ここで、

$J_{z \sigma_{b} / \sigma_{a}=1}$ は均一な組織でモデル内が満たされている場合の
垂直方向電流密度、 $J_{z \sigma_{b} / \sigma_{a}}$ は導電率 $\sigma_{a}$ および $\sigma_{b}$ の組織か らなる場合のそれである。同図より、外部組織の導電率が 内部組織のそれと比較して小さくなると、内部組織の電流 密度が増加することがわかる。 $\sigma_{b} / \sigma_{a}=0.10$ 場合、内部お よび外部組織の底面の電流密度は均一な場合のそれと比較 してそ扎ぞれ3倍および0.3倍になっている。次に、外部組 織の遒電率が内部組織のそれと比較して大きくなると、内 部組織の電流密度が極端に小さくなっている。 $\sigma_{b} / \sigma_{a}=100$ とき、内部および外部組織の底面では均一組織の場合と比 較してそれぞれ0.14および1.4倍になっている。同図から、 モデル底面では電流密度の比は導電率の比上ほほ等しいこ とがわかる。このことから、底面付近では内部および外部 組織の電界強度はほぼ等しくなるように分布することが理 解される。また、モデルの頂面においては、電流密度は内 外部組織の導電率の比にかかわらず、ほぼ一定であること がわかる。

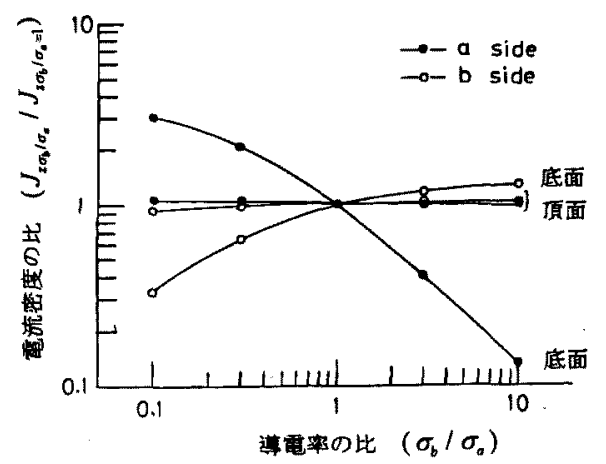

図 9 モデル頂面中央および底面中央における内外組 織の遒電率の比 $\left(\sigma_{b} / \sigma_{a}\right)$ 亡垂直方向電流密度 の比 $\left(J_{z \sigma_{b} / \sigma_{a}} / J_{z \sigma_{b} / \sigma_{a}=1}\right)$ の関係

Fig. 9 Relations between ratio of conductivities $\left(\sigma_{b} / \sigma_{a}\right)$ and ratio of the vertical current densities $\left(J_{z \sigma_{b} / \sigma_{a}} / J_{z \sigma_{b} / \sigma_{a}=1}\right)$ at the points of the model top and bottom.

\section{5．考察一筋肉組織が脂肪組織に囲まれた場合の 解析例一}

3 節で内外部組織の導電率の比がモデル内の電流密度に 与える影響についての一般的な傾向を述べた。少し具体的 な例として箭肉組織が脂肪組織（厚さ $10 \mathrm{~mm})$ に囲まれてい る場合について検討する。このとき、筋肉組織の導電率を

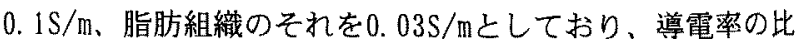
$\sigma_{b} / \sigma_{a}=0.3$ あ゙る。図10にモデルの $\mathrm{r} / \mathrm{R}$ と内外部組織の垂 直方向をもつ電流密度の関係を示す。同図から、筋肉組織 内の電流密度は脂肪組織内のそれと比較して大きく、モデ ルの上部から下部にかけて大きくなっていることがわかる。 また、脂肪組織層の先端部分 $(\mathrm{z} / \mathrm{h}=0.9, \mathrm{r} / \mathrm{R}=1)$ で誘導電 流密度の值がモデル中部、下部より大きく求められている。 これはモデル頂面先端で電界強度の集中が起こり、このた め、誘導電流密度の值が大きくなっているものと考えられ 
る。図11に $\mathrm{r} / \mathrm{R}$ と水平方向電流密度の関係を示す。同図から、 内外部組織の境界面で電流密度の水平方向成分は大きくな るが、モデルの中心付近ではこの值は著しく減少する。図 12 筋肉組織と脂肪組織の導電率の比 $\left(\sigma_{b} / \sigma_{a}\right)$ がそれら の垂直方向の電流密度の比 $\left(J_{z \sigma_{b} / \sigma_{a}} / J_{z \sigma_{b} / \sigma_{a}=1}\right)$ に与元る影 響を示す。本モデルの場合、 $\sigma_{b} / \sigma_{a}=0.3$ である゙、このと き脂肪組織内の垂直方向電流密度は底面で均一組織のそれ と比較して約0.33倍、筋肉組織のそれは約1.1倍になってい

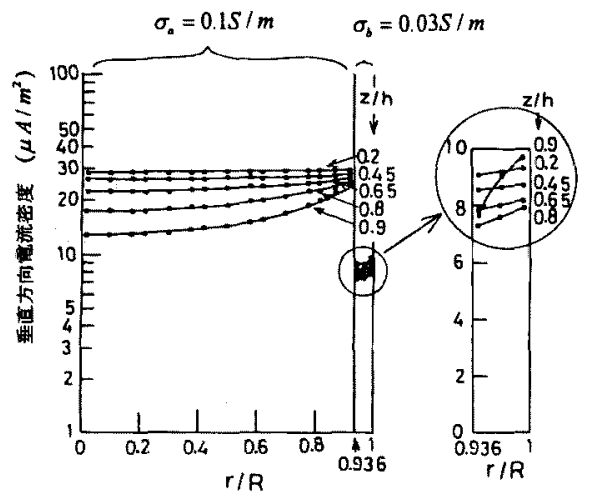

図10 モデル内半径方向の距離 $\mathrm{r} / \mathrm{R}$ 垂直方向電流密度 の関係（筋肉組織が脂肪組織に囲まれた場合、 外部電界 $1 \mathrm{kV} / \mathrm{m})$

Fig. 10 Distributions of the vertical current densilies inside the model along its $\mathrm{r} / \mathrm{R}$. (The case that muscle tissue is surrounded with fat tissue, external field $1 \mathrm{kV} / \mathrm{m}$ )

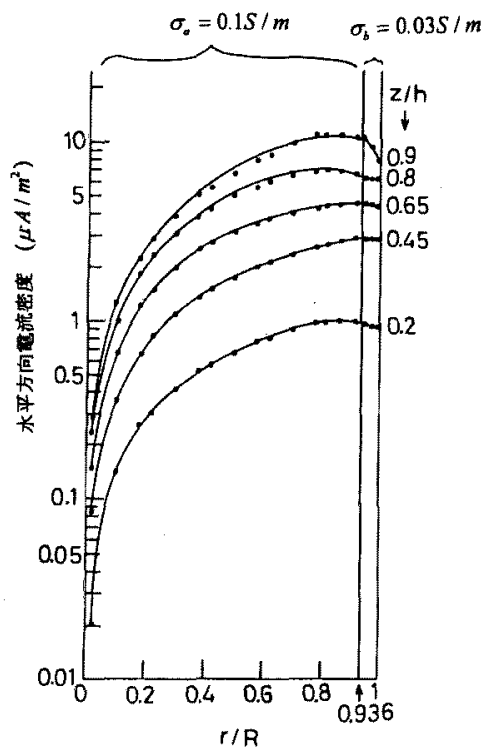

図11 モデル内半径方向の距﨎 $\mathrm{r} / \mathrm{R}$ と水平方向電流密度 の関係（筋肉組織が脂肪組織に囲まれた場合、 外部電界 $1 \mathrm{kV} / \mathrm{m}$ )

Fig. 11 Distributions of the horizontal current densities inside the model along its $r / R$. (The case that muscle tissue is surrounded with fat issue, external field $1 \mathrm{kV} / \mathrm{m}$ )
る。言いかえれば、脂肪組織が $10 \mathrm{~mm}$ 程度の場合、筋肉組織 内の電流はほぼ10\%程度增加する。これらの值は円柱と半球 からなる人体モデルで、箭肉組織が脂肪組織（児さ10min） に囲まれている場合とよく一致する( ${ }^{(8)}$ 。すなわち、この程 度の脂肪層の厚さでは筋肉組織内の電流密度はあまり大き な影響を受けないことが明らかになった。

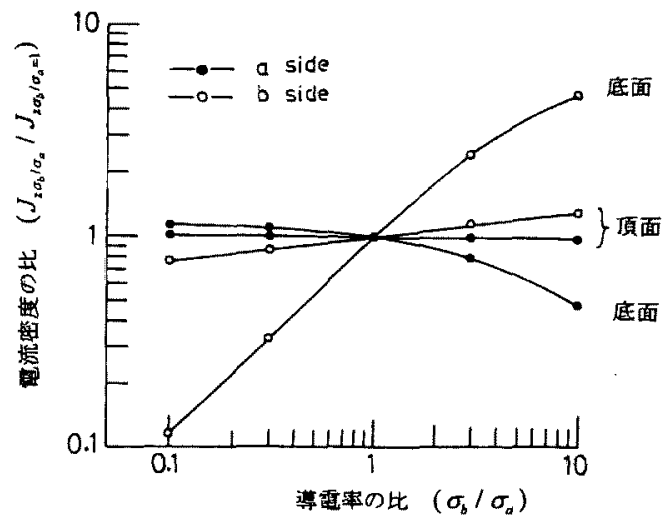

図12 内外組織の導電率の比 $\left(\sigma_{b} / \sigma_{a}\right)$ と垂直方向電 流密度の比 $\left(J_{z \sigma_{b} / \sigma_{a}} / J_{z \sigma_{b} / \sigma_{a}=1}\right)$ の関係（外部 組織の厚さ $10 \mathrm{~mm}$ )

Fig. 12 Relations between ratio of conductivities $\left(\sigma_{b} / \sigma_{a}\right)$ and ratio of the vertical current densities $\left(J_{z \sigma_{b} / \sigma_{a}} / J_{z \sigma_{b} / \sigma_{a}=1}\right)$. (Thickness of the external tissue $10 \mathrm{~mm}$ )

\section{6. むすひ}

水平拉よび垂直方向の誘導電流密度分布が実験的に明ら かにされているKaune等の垂㨁円柱モデルを用いて、同モデ ルが導電率の異なる内部および外部組織で構成された場合 について、その内部誘導電流密度の分布を有限要素法によ り解析した。以下にこれらの結果を述べる。

（1）PVC容器を考慮した円柱モデル内部に誘導される水平 および垂直方向電流密度の有限要素法による解析結果は Kaune等の実験結果の範囲内にありよく一致している。すな わち、同モデル内部に誘導される水平および垂直方向電流 密度を有限要素法により解析することの妥当性がKaune等の 実験結果を用いて検証された。

（2）PVC容器（厚さ4.5m、比誘電率 3）の影響により、壬 デル内に誘導される電流密度はその底面付近で2. 3\%程度增 加する。

（3）内部および外部組織からなる円柱モデル底面において、 垂直方向電流密度の比㴧電率の比と添ぼ等しいことから、 底面付近では内部および外部組織の電界強度はほぼ等しく なるように分布することがわかる。本モデル頂面における 垂直方向電流密度は内外部組織の導電率の比にかかわらず ほぼー定である。なお、モデルの同一高さの内外部組織境 界面で両組織の垂直方向電流密度の比はそれらの組織の遒 電梁の比とほぼ等しくなっていることが確かめられた。 
（4）同モデル内部に誘導される電流密度の水平方向成分は 上部で大きく、中部、下部にゆくに従って著しく減少する。 なお、モデル同一高さにおける水平方向電流密度は両組織 の境界面でほぼ等しくなっていることが確かめられた。

（5）同モデルで、内部および外部組織内の導電率のちがい による各組織内の電流密度の集中度を明らかにした。

（6）同モデルにおいて筋肉組織が脂肪組織（厚さ $10 \mathrm{~mm}$ ）で 囲まれている様な場合、筋肉組織の電流密度はほぼ1.1倍、 脂肪組織のそれはほぼ0.33倍になる。言いかえれば、解析 条件下で脂肪組織の厚さが $10 \mathrm{~mm}$ 程度ある場合、筋肉組織内 の電流密度は、ほぼ10\%程度増加する。すなわち、この程度 の脂肪層の厚さで㤬筋肉組織内の電流密度はあまり大きな 影響をうけないことが明らかになった。

今後、筆者等は回転対称なものとしてモデル化した人体 の頭部（頭皮、頭骨、脳脊䯣液、脳からなる）に焦点をあ て、本方法を応用して詳細に解析する予定である。

(平成8年4月23日受付、同年10月9日再受付)

\section{文献}

(1) B. W. Wilson, R. G. Stevens and L. E. Anderson, Extremely Low Frequency Electromagnetic Fields : The Question of Cancer", Battelle Press, Columbus. Richland, pp. 17-46 (1990)

(2) Shiau Y. and Valentino A. :"ELF Electric Coupling to Dielectric Spheroidal Models of Biological 0bject", IEEE Trans. Biomedical Engineering, BME28, 6, pp. 429- 437 (1981).

(3) Spiegel R. J. :"Numerical Determination of Induced Currents in Humans and Baboons Exposed to $60 \mathrm{~Hz}$ Electric Fields ", IEEE Trans. Electromagnetic Compatibility, EMC-23, 4, pp. 382-390 (1981).

（4）千葉、伊坂、大野木 : " 交流電界中の人体モデルに誘 導される電流密度の解析”、電子情報通信学会論文誌 B-II , Vol. J77-B-II , No. 2, pp. 93-100 (1994).

(5) Chen K., Chuang C. and Lin C. :" Quantification of Interaction Between ELF-LF Electric Fields and Human Bodies", IEEE Trans. Biomedical Engineering, BME-33, 8, pp. 746-756 (1986).

(6) W. T. Kaune and F. A. McCreary:"Numerical Calculation and Measurement of $60-\mathrm{Hz}$ Current Densities Induced in an Upright Grounded Cylinder" , Bioelectromagnetics 6, pp. 209-220 (1985).

(7) Chiba A., Isaka K., Yokoi Y., Nagata M. and Kitagawa M. : "Application of Finite Element Method to Analysis of Induced Current Densities Inside Human Model Exposed to 60-Hz Electric Field", IEEE Trans. Power Apparatus and Systems, PAS-103, 7, pp. 1895-1901 (1984).

（8）千葉、伊坂、横井、大野木 : " 電力周波数電界内に置
かれた導電率が異なる二種類の組織を有する人体モデ ル内部の電流分布”、電気学会論文誌 $B$, Vol. 109-B, No. 6, pp. 258-264 (1989).

(9) W. T. Kaune and W. C. Forsythe, "Current Densities Measured in Human Models Exposed to $60-\mathrm{Hz}$ Electric Fields", Bioelectromagnetics Vol. 6, pp. 13-32 (19.85)

(10) 河野、宅間、”数值電界計算法”、コロナ社, pp. 160162 (1980).

(11) 0.C. ツィエンキーヴィッツ著、吉識、山田監訳、三訂 版、”マトリックス有限要素法”、培風館, pp. 205206 (1984).

(12) S. Rush, J. A. Abildshov and R. McFee, "Resistivity of Body Tissues at Low Frequencies", Circulation Research, 7, No. 40 (1963).

(13) E. Carstensen, "Biological Effects of Transmission Line Fields ", Elsevier Science Publishing Co. Inc., New York, pp. 40-44 (1987).

千葉 敦生（正員）1945年 3 月28日生まれ。45年 3 月 鳥取大学工学部電気工学科卒、同年米子高専電 気工学科助手、現在、同教授.人体に対する静 電誘導の電気的特性に関する研究に従事. 工博. 電子情報通信学会、日本シミュレーション学会、 IEEE各会員.

伊坂 勝生（正員）1944年 3 月 3 日生まれ．66年 3 月

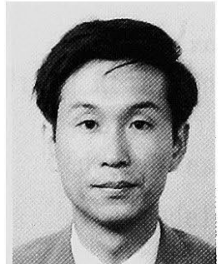
広島大学工学部電気工学科卒. 68年東京大学院 工学系研究科修士課了. 71 年同博士課程了. 同 年 4 月より徳島大学工学部電気工学科に勤務. 88年 7 月より同教授、現在に至る. 工博. 75 年 5 月電気学会論文賞受賞. 静電気学会、環境科 学学会、IEEE各会員. 